\title{
PERENCANAAN BISNIS TEPUNG KOMPOSIT DENGAN SISTEM BAGI HASIL
}

\section{COMPOSITE FLOUR BUSINESS PLANNING WITH REVENUE SHARING SYSTEM}

\author{
Darsasa Herdiana Anggriyanto1), Marimin²), dan Yandra Arkeman²) \\ ${ }^{1)}$ Sekolah Bisnis, Insititut Pertanian Bogor \\ ${ }^{2}$ Departemen Teknologi Industri Pertanian, Insititut Pertanian Bogor \\ *email: marimin@indo.net.id \\ Makalah: Diterima 8 Mei 2019; Diperbaiki 22 Agustus 2019; Disetujui 15 September 2019
}

\begin{abstract}
The successful of composite flour business planning is required a feasibility study and revenue sharing system. The objective of this research is to design the business plan for composite flour through feasibility study and revenue sharing system. The exploratory research method with observation approach was implemented in this research. The feasibility aspects to observed are market, technical, human resource and organization, environment and financial aspect for revenue sharing. The result showed that tapioca flour and mocaf flour were potential substitutes for wheat flour. Based on the availability of raw materials, mocaf flour has a minimum availability of 10.000 tons / year, therefore it had 29 tons/day to substituted wheat flour. This research designed the substitution of wheat flour were 5\% of mocaf flour and 5\% of tapioca flour. The feasibility study showed that the payback period (PBP) was 3 years and 6 months while Break Event Point (BEP) was 153.258.997 Kg/year. The result concluded that this business planning were feasible to operate. Further, this research also designed 2 revenue sharing scenarios as recommended by National Sharia Board. Finally, this research succeeds to designed a feasible business for composite flour with revenue sharing.
\end{abstract}

Keywords: business plan, revenue sharing, feasibility, composite flour

\section{ABSTRAK}

Keberhasilan perencanaan bisnis tepung komposit memerlukan kajian kelayakan dan sistem bagi hasil yang tepat.Penelitian ini bertujuan untuk menyusun perencanaan bisnis untuk tepung komposit melalui kajian kelayakan dan sistem bagi hasil. Metode eksploratori dengan pendekatan observasi diimplementasikan pada penelitian ini. Aspek kelayakan yang diteliti meliputi pasar, teknis, sumberdaya dan organisasi, lingkungan dan keuntungan untuk bagi hasil. Hasil analisis menunjukkan bahwa tepung tapioka dan mocaf berpotensi untuk menggantikan tepung gandum. Berdasarkan ketersediaan bahan baku, tepung mocaf memiliki ketersediaan hingga 10.000 Ton/ tahun, sehingga terdapat 29 Ton/hari untuk mensubstitusi tepung tapioca. Penelitian ini berhasil merancang scenario substitusi 5\% untuk tepung mocaf dan 5\% untuk tepung tapioka. Hasil kajian kelayakan menunjukkan bahwa nilai payback period adalah 3 tahun 6 bulan sedangkan Break Event Point adalah 153.258.997 Kg/tahun. Hasil ini dapat memberikan kesimpulan bahwa perancanaan bisnis tepung komposit ini layak untuk dilaksanakan. Penelitian ini juga telah berhasil merancang 2 skenario bagi hasil seperti yang telah direkomendasikan oleh Dewan Syariah Nasional. Akhirnya, penelitian ini telah berhasil merancang bisnis tepung komposit yang layak dengan sistem bagi hasil.

Kata kunci: perencanaan bisnis, bagi hasil, kelayakan, tepung komposit

\section{PENDAHULUAN}

Indonesia saat ini merupakan konsumen terigu yang sangat besar didunia. Saat ini, Indonesia memiliki 30 pabrik terigu dengan total kapasitas keseluruhan sebesar 11,4 juta MT/tahun, dengan pertumbuhan konsumsi tepung terigu pada tahun 2012 sebesar 8,93\%, tahun 2013 sebesar 4,14\%, tahun 2014 sebesar 5,09\%, pada tahun 2015 mengalami penurunan sebesar $2,58 \%$ namun pada tahun 2016 mengalami kenaikan kembali sebesar 6,34\% (Aptindo, 2017). Data tersebut menunjukkan bahwa Indonesia masih memiliki ketergantungan terhadap tepung terigu dengan tingkat permintaan yang terus meningkat.
Langkah yang dapat ditempuh untuk mengurangi ketergantungan tersebut adalah dengan menggali dan mengembangkan sebanyak mungkin bahan pangan berbasis lokal, baik bahan pangan baru, maupun bahan pangan yang sudah dikenal tetapi belum cukup banyak dikembangkan (Syah et al., 2009). Menurut Richana (2010), cita rasa kue yang dihasilkan dari tepung lokal tidak berbeda dengan kue yang dibuat dari $100 \%$ tepung terigu. Sehingga pangan lokal tidak kalah bersaing dengan produk impor dari segi sifat fungsional pangannya.

Kebutuhan akan alternatif pangan bergizi dengan harga terjangkau membuka peluang untuk memproduksi olahan dari tepung terigu yang disubstitusi dengan tepung mocaf yang disebut dengan tepung komposit. Mocaf merupakan produk 
turunan dari tepung singkong yang menggunakan prinsip modifikasi sel singkong secara fermentasi (Subagio, 2007). Selain itu, teknologi pembuatan olahan tepung komposit tidaklah terlalu rumit dan dapat menggunakan peralatan yang sederhana. Menurut Yulifianti et al. (2012), masalah yang ditemukan pada ubikayu adalah masa panen satu kali dalam setahun, kemudian ubikayu mudah rusak (perisahble) setelah dipanen dan bersifat rowa (volumerous) sehingga harus segera diproses lebih lanjut. Petani sering mengalami kerugian karena harus menjual hasil panen dengan harga murah yang disebabkan umbi segar tidak tahan lama disimpan. Pengolahan menjadi produk mocaf merupakan alternatif untuk mengatasi hal tersebut. Menurut Hadi (2013), mocaf dapat disimpan selama enam bulan sebagai cadangan bahan baku saat ubikayu sulit diperoleh, sehingga produksi tepung dapat berlangsung sepanjang tahun. Selain itu, perlu pengaturan waktu tanam dan panen ubikayu secara bergilir agar kontinuitas pasokan bahan baku dapat terjamin. Untuk melakukan pendirian industri tepung komposit diperlukan adanya perencanaan bisnis.

Perencanaan merupakan fungsi utama dalam aktivitas keseharian. Perencanaan merupakan proses yang menentukan tujuan organisasi yang ingin dicapai dan yang harus dilakukan untuk mencapai tujuan itu dengan menggunakan sumberdaya manusia, keuangan, material, mesinmesin dan metode yang diperlukan dalam batasbatas yang diperlukan, secara efektif dan efisien (Abdullah, 2014). Tujuan perencanaan bisnis adalah agar kegiatan bisnis yang akan dilakukan maupun yang sedang berjalan tetap berada di jalur yang benar sesuai dengan yang direncanakan (Rangkuti, 2005). Pengambilan keputusan bisnis dipengaruhi oleh pemegang saham, pinjaman dana, pekerja, pemasok, pesaing, pemerintah dan masyarakat, sehingga tujuan dan strategi yang konsisten dengan semua kepentingan tersebut diperlukan. Setelah itu, dilakukan studi kelayakan untuk mengetahui proyek tersebut layak atau tidak.

Studi kelayakan merupakan suatu analisis perencanaan yang sistematis dan mendalam atas setiap faktor yang memiliki pengaruh terhadap kemungkinan proyek untuk mencapai keberhasilan. Semua data, fakta dan berbagai pendapat yang dikemukakan dalam studi kelayakan tersebut akan menjadi dasar dalam pengambilan keputusan apakah proyek yang bersangkutan akan direalisasikan, dibatalkan atau dikaji ulang (Eschenbach, 1992). Tujuan dari studi kelayakan adalah untuk mengidentifikasi apakah suatu gagasan bisnis layak masuk dalam marketplace dan menghindari terjadinya investasi yang tidak menguntungkan karena usaha yang tidak layak (Subagyo, 2008).

Investasi merupakan bagian dari fikih muamalah, yang berlaku kaidah hukum asal dalam semua bentuk muamalah dapat dilakukan kecuali terdapat dalil yang mengharamkannya (Djazuli,
2006). Menurut Pardiansyah (2017), tidak semua jenis investasi diperbolehkan syariah seperti yang mengandung penipuan dan kebohongan atau mengandung unsur-unsur kegiatan yang dilarang syariat islam. Investasi masih banyak dilakukan oleh oknum perorangan, koperasi atau entitas tertentu untuk mendapatkan keuntungan yang besar tanpa memperdulikan norma-norma yang berlaku, baik norma positif atau norma agama.

Secara umum kaum muslim menolak riba yang menetapkan pembayaran sejumlah tertentu yang didasari oleh larangan investasi untuk bisnis yang dikategorikan haram dan menjalankan seperangkat hukum islam dengan memberikan modal atau pembiayaan yang halal (Segrado, 2005). Diawali pada tahun 2004 di Arab terdapat 200 dana investasi islam, 70 perusahaan asuransi islam, dengan total operasi pasar melebihi 150 miliar dollar (Iqbal dan Molyneux, 2005). Menurut Abdullah (2014), perencanaan bisnis syariah merupakan aktivitas bisnis yang dilakukan menurut ketentuan syariah (hukum Islam) sehingga perencanaan dalam manajemen bisnis syariah adalah proses pencapaian tujuan bisnis syariah atau keuntungan yang berkelanjutan dengan menggunakan sumberdaya organisasi (bisnis syariah). Sumberdaya tersebut meliputi penggunaan sumberdaya manusia, keuangan, material, peralatan dan metode yang diperlukan dalam batas-batas yang diperbolehkan oleh syariat islam, secara efektif dan efisien.

Penelitian ini bertujuan untuk melakukan perencanaan bisnis produksi tepung terigu yang disubstitusi sebagian dengan tepung lokal dan menganalisis kelayakan bisnis produksi tepung terigu yang disubstitusi sebagian dengan tepung berbahan dasar ubikayu dengan sistem bagi hasil. Pada bagian selanjutnya akan disampaikan metodologi penelitian yang berisi kerangka pemikiran dan teknik yang digunakan untuk menjawab tujuan penelitian. Bagian hasil dan pembahasan akan mensintesis hasil pengolahan data serta aspek yang perlu diperhatikan dalam perencanaan bisnis tepung komposit. Pada bagian akhir, simpulan dan saran akan menjawab tujuan penelitian dan menyampaikan rekomendasi untuk perencanaan bisnis tepung komposit yang layak melalui sistem bagi hasil.

\section{METODE PENELITIAN}

\section{Kerangka Pemikiran}

Penelitian ini diinisiasi dari adanya potensi pengembangan usaha tepung komposit, karena ketersediaan bahan baku yang mencukupi dan permintaan yang juga tinggi. Pendirian pabrik atau Usaha Kecil Menengah dengan kapasitas yang sesuai adalah salah satu solusi untuk menampung potensi bahan baku dan mengolahnya menjadi tepung komposit untuk memenuhi permintaan konsumen. Proses pendirian pabrik dan usaha 
tersebut memerlukan analisis berbagai faktor, agar bisnis yang dijalankan memiliki keberlanjutan dan kepastian keuntungan. Aspek aspek tersebut dikenal dengan aspek kelayakan, terdiri dari aspek pasar, teknis, Sumber Daya Manusia (SDM) serta aspek lingkungan. Kelayakan aspek-aspek tersebut ternyata tidak menjadi satu jaminan yang pasti untuk menjamin tingkat keuntungan yang sesuai. Sehingga, diperlukan pengkajian aspek finansial dengan prinsip bagi hasil. Prinsip bagi hasil keuntungan penting untuk dirancang pada satu bisnis baru, agar semua aktor yang terlibat dapat termotivasi untuk berproduksi dan tidak merasa dirugikan untuk berinvestasi. Kerangka penelitian dapat dilihat pada Gambar 1.

Metode yang dilakukan dalam penelitian ini dilakukan dengan riset eksploratori menggunakan pendekatan observasi serta analisa data sekunder. analisa yang dilakukan bertujuan untuk mengamati aspek pasar, aspek teknis, aspek sumber daya manusia dan organisasi, aspek lingkungan serta aspek finansial. Analisa dari beberapa aspek tersebut diperoleh berdasarkan hasil observasi lapangan dari kunjungan ke perusahaan pengolahan tepung komposit dan studi literatur dari narasumber dan pakar yang berkaitan dengan penelitian ini.

Data dan informasi dikumpulkan untuk keperluan analisis aspek-aspek yang berkaitan dengan penelitian ini. Data yang dikumpulkan meliputi data primer dan sekunder. Pengambilan contoh responden dalam penelitian ini menggunakan metode purposive sampling, yang sampel responden ditetapkan secara sengaja oleh peneliti. Sampel responden yang diambil merupakan responden yang mengetahui pengetahuan tentang industri pengolahan tepung yang mencakup aspek produksi, operasi, manajemen dan finansial.

\section{Analisis Kelayakan dan Aspek Manajemen}

Analisa yang dilakukan dalam perencanaan pendirian pabrik pengolahan tepung komposit meliputi lima aspek, menurut Umar (2003), yakni aspek pasar, aspek teknis, aspek lingkungan, aspek sumber daya manusia dan organisasi, serta aspek finansial. Pengolahan data dari masing-masing aspek tersebut dijelaskan sebagai berikut:

\section{Aspek Pasar dan Pemasaran}

Pengolahan data dari aspek pasar berasal dari data sekunder yang akan dilakukan dengan metode deskriptif. Dalam aspek ini meliputi permintaan dan penawaran produk tepung, serta informasi harga tepung di wilayah Bogor dan sekitarnya. Pengamatan ini bertujuan untuk mengetahui informasi mengenai harga bahan pendukung untuk tepung komposit saat ini dan yang akan datang.

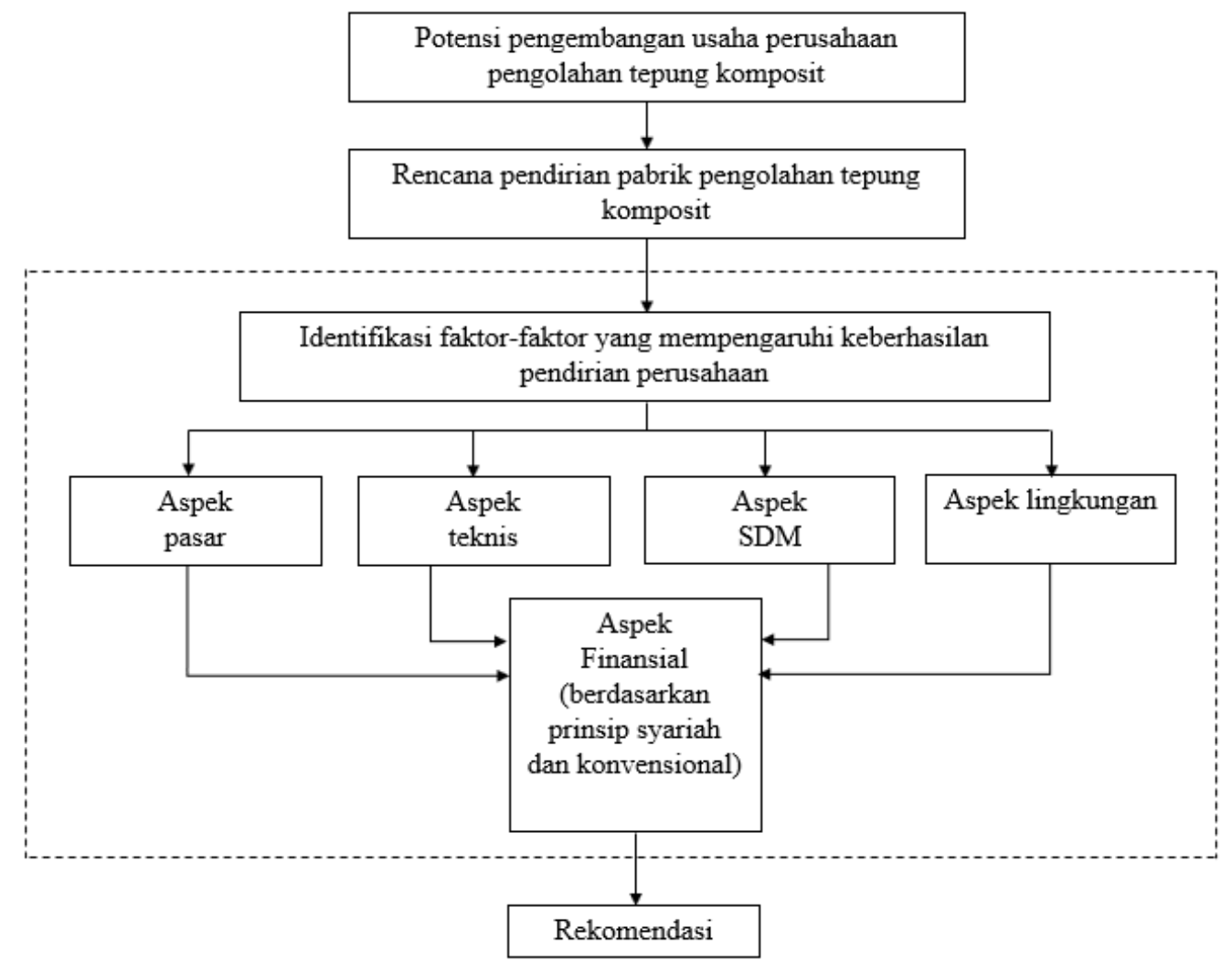

Gambar 1. Kerangka pemikiran penelitian 


\section{Aspek Teknis}

Dalam aspek teknis ini ditinjau kelayakan dan kemampuan implementasi rencana teknis kegiatan atau usaha. Informasi mengenai aspek teknis ini diperoleh dari data primer hasil observasi lapangan pada perusahaan pengolahan tepung komposit dan dijabarkan secara deskriptif. Analisis meliputi evaluasi yang mencakup tahap awal perencanaan pendirian pabrik sampai dengan kegiatan operasional serta tahap produksi. Pada tahap produksi mencakup teknis dan teknologi yang digunakan sampai dengan input produksi lain yang spesifik dan mempengaruhi kegiatan operasional perusahaan. Pengamatan faktor teknis produksi yang dilakukan dalam analisa hanya dibatasi pada faktor-faktor produksi yang dapat dikontrol.

\section{Aspek SDM dan Organisasi}

Kajian dalam aspek ini mempunyai tujuan yaitu menganalisa ketersediaan SDM yang akan mengoperasikan perusahaan. Informasi mengenai aspek SDM dan organisasi ini diperoleh dari metode observasi dan dijabarkan dengan metode deskriptif. Penelitian pada aspek ini mencakup pada beberapa jumlah divisi yang dibutuhkan, serta analisis kebutuhan tenaga kerja yang dibutuhkan untuk mengelola dan mengoperasikan perusahaan agar berjalan sistematis.

\section{Aspek Lingkungan}

Analisa yang dilakukan dalam aspek lingkungan bertujuan untuk mengetahui daerah yang mendapatkan izin serta kondisi lingkungan dan topografi yang sesuai untuk pendirian pabrik pengolahan tepung komposit. Informasi yang digunakan adalah data primer hasil observasi lapangan di Kabupaten Bogor dan dijabarkan dengan menggunakan metode deskriptif. Pengamatan pada aspek finansial akan berhubungan dengan informasi mengenai berapa besar biaya investasi yang harus dikeluarkan untuk pembelian dan pengolahan lahan. Selain itu juga untuk mengetahui ketersediaan bahan baku dan besarnya dana yang diperlukan untuk pendirian pabrik.

\section{Aspek Finansial}

Analisis aspek finansial dilakukan dalam dua tahap yaitu tahap penentuan prinsip-prinsip syariah berdasarkan perundang-undangan dalam Fatwa Dewan Syariah Nasional Majelis Ulama Indonesia yang digunakan dalam analisis kelayakan finansial dan tahap pelaksanaan analisis kelayakan finansial yang memiliki tujuan untuk mengetahui kelayakan implementasi pembangunan perusahaan ditinjau dari segi finansial. Data yang digunakan pada aspek finansial ini menggunakan gabungan dari beberapa aspek sebelumnya. Penggabungan ini bertujuan untuk mengetahui besarnya dana awal yang harus diinvestasikan dalam pendirian usaha dan juga biaya yang harus dikeluarkan untuk modal kerja dan kegiatan operasional.

\section{Sistem Bagi Hasil}

Sistem bagi hasil merupakan prinsip yang dilakukan berdasarkan syariah islam yang disebut mudharabah. Mudharabah merupakan akad kerjasama suatu usaha antara dua pihak dimana pihak pertama menyediakan seluruh modal, sedang pihak kedua bertindak selaku pengelola dan keuntungan dibagi di antara mereka sesuai kesepakatan yang dituangkan dalam kontrak (DSN2000).

\section{HASIL DAN PEMBAHASAN}

Menurut Marimin dan Sutiyono (2002), perencanaan dalam agroindustri perlu memperhatikan potensi produk, ketersediaan bahan baku, potensi pasar dan kelayakan finansial investasi usaha. Pada bagian-bagian selanjutnya akan disampaikan aspek-aspek kelayakan yang harus diperhatikan dalam perencanaan bisnis tepung komposit.

\section{Analisis Kelayakan Bahan Baku}

Tepung komposit merupakan tepung yang terdiri dari lebih dari satu jenis tepung dengan komposisi tertentu yang bertujuan untuk mendapatkan karakteristik bahan yang sesuai untuk produk olahan yang diinginkan atau untuk mendapatkan sifat fungsional tertentu (Widowati, 2009). Menurut penelitian Lala et al. (2013), tepung komposit terigu dan tepung mocaf dengan perbandingan 75:25 layak digunakan sebagai bahan baku mie instan dan menurut Firdaus et al. (2017) dengan bahan dasar mocaf dan menghasilkan produk kue dan cemilan kering. Hasil penelitian pada Firdaus et al. (2017) memberikan informasi bahwa tepung tapioka dan tepung mocaf memiliki potensi sebagai pengganti tepung terigu.

Kapasitas merupakan tingkat kemampuan berproduksi secara optimum dari sebuah fasilitas yang dinyatakan sebagai jumlah output pada satu periode waktu tertentu (Rangkuti, 2005). Berdasarkan ketersediaan bahan baku, tepung mocaf memiliki ketersediaan paling sedikit yakni 10.000 ton/tahun, maka tepung mocaf yang dapat disediakan untuk substitusi sebagian tepung terigu adalah 29 ton/hari. Tepung mocaf yang di substitusi sebesar $5 \%$ dan tepung tapioka sebesar 5\%. Oleh karena tepung terigu yang harus disiapkan adalah 522 ton/hari. Tepung terigu sebesar 522 ton/hari dapat dihasilkan dengan menggiling 705.405 MT gandum/hari.

Bahan baku yang digunakan dalam pembuatan tepung komposit yakni gandum, tepung mocaf, dan tepung tapioka. Gandum yang digunakan terdiri atas dua jenis yakni hard wheat dan soft wheat dengan perbandingan 8:2 untuk menghasilkan 
tepung terigu berprotein tinggi dan tepung terigu berprotein rendah. Jenis terigu yang dibuat dari gandum hard wheat sesuai untuk pembuatan roti dan gandum soft wheat sesuai untuk pembuatan kue, pastel dan kue kering (US Wheat Associates, 1981). Tepung mocaf dan tepung tapioka yang digunakan untuk mengurangi komposisi tepung terigu dalam tepung komposit sebesar $10 \%$ dari total tepung terigu yang diproduksi.

\section{Aspek Manajemen Produksi}

Pada aspek teknologi dan proses produksi pembuatan tepung komposit, terdapat beberapa aspek yang perlu diperhatikan yaitu penanganan bahan baku dan proses produksi tepung komposit. Penanganan bahan baku dilakukan saat bahan baku tiba dan penyimpanan bahan baku hingga bahan baku siap untuk diproses lebih lanjut. Proses utama dalam pembuatan tepung komposit dilakukan sejak bahan baku dibersihkan hingga produk dikemas.

Pada aspek manajemen, perencanaan bisnis tepung komposit perlu memperhatikan struktur organisasi dan kebutuhan tenaga kerja. Struktur organisasi berhubungan dengan setiap posisi orangorang yang akan melakukan tugas dalam suatu perusahaan. Struktur organisasi yang jelas dapat memudahkan pengordinasian anggota organisasi sehingga tugas dan sumber daya terbatas dapat terdistribusi dengan baik (Kasmir dan Jakfar, 2004). Rangkaian kegiatan operasional akan dijalankan sesuai dengan bagian bidangnya masing-masing. Struktur organisasi industri tepung komposit terbagi menjadi beberapa bagan utama yakni direktur, manajer dan staf. Tenaga kerja yang berkontribusi dalam industri tepung komposit terdiri dari tenaga kerja produksi dan tenaga kerja non produksi.Tenaga kerja langsung yang terlibat dalam produksi tepung komposit adalah 35 orang. Tenaga kerja yang tidak terlibat langsung dalam produksi adalah 64 orang.

Berdasarkan skala industri tepung komposit yang didirikan, industri tepung komposit membutuhkan permodalan yang cukup besar, karena itu bentuk badan usaha yang dibentuk adalah perusahaan, pencerminannya berdasar pada daya serap terhadap tenaga kerja, tingkat teknologi, nilai output dan nilai tambah yang mewarnai industri pengolahan (BPS, 1987). Mekanisme yang harus dipenuhi dalam pendirian perseroan terbatas adalah memiliki akta resmi yang diperoleh dari notaris yang didalamnya tercantum nama lain dari perusahaan, modal, bidang usaha, alamat perusahaan.

Pendirian industri di Bogor memerlukan perizinan usaha di wilayah Bogor, antara lain Surat Keterangan Domisili Perusahaan, Surat Izin Usaha Dagang (SIUP), Izin Usaha Industri (IUI), Tanda Daftar Perusahaan (TDP) dan izin edar BPOM MD. Pengurusan surat-surat perizinan tersebut didasarkan pada SK Menteri Perindustrian RI No 41/MIND/Per/6/2008 dan untuk pendirian pabrik perlu membuat izin mendirikan bangunan (IMB) sehingga diperoleh izin pendirian bangunan (IPB). Pemeriksaan kelayakan pendirian bangunan dilakukan setiap 5 tahun sekali.

Limbah pada industri tepung komposit terdiri atas limbah padat. Limbah padat diperoleh dari hasil penyortiran, pembersihan dan penggilingan. Limbah padat yang dihasilkan oleh industri tepung komposit berupa bran, pollard, germ, dan tepung produksi. Limbah padat hasil pengolahan gandum dapat dijual kembali sebagai pakan ternak.

\section{Aspek Finansial \\ Prakiraan Biaya Produksi dan Penerimaan}

Biaya yang digunakan dalam kegiatan produksi terdiri atas biaya tetap dan biaya variabel. Biaya tetap adalah biaya yang dikeluarkan untuk memperoleh faktor produksi yang tidak dapat dirubah jumlahnya. Ringkasan mengenai prakiraan permintaan dapat dilihat di Tabel 1 .

Biaya variabel adalah biaya yang dikeluarkan saat kegiatan produksi berlangsung (Kardono dan Hanani, 2004). Biaya variabel pada tahun pertama industri berdiri adalah $50 \%$ dari total biaya produksi normal, biaya variabel pada tahun kedua industri berdiri adalah $75 \%$ dari total biaya produksi normal, biaya produksi tahun ketiga $100 \%$ dari biaya produksi normal karena industri perlu menyesuaikan kapasitas produksi dengan target produksi.

Tabel 1. Prakiraan penerimaan industri tepung komposit

\begin{tabular}{|c|c|c|c|c|c|c|c|}
\hline \multirow[b]{2}{*}{$\begin{array}{l}\text { Tahu } \\
\text { n ke- }\end{array}$} & \multirow[b]{2}{*}{$\begin{array}{c}\text { Tingkat } \\
\text { Produksi }\end{array}$} & \multicolumn{2}{|c|}{$\begin{array}{c}\text { Jumlah Produksi Tepung } \\
\text { Komposit }\end{array}$} & \multirow{2}{*}{$\begin{array}{c}\text { Harga } \\
\text { Produk } \\
\text { Tepung } \\
\text { Komposit } \\
(\mathbf{R p} / \mathrm{Kg})\end{array}$} & \multirow{2}{*}{$\begin{array}{c}\text { Jumlah } \\
\text { Produksi Bran, } \\
\text { Pollard } \\
\text { (Ton/th) }\end{array}$} & \multirow{2}{*}{$\begin{array}{c}\text { Harga } \\
\text { Produk } \\
\text { Bran, } \\
\text { Pollard } \\
\text { (Rp/Kg) }\end{array}$} & \multirow{2}{*}{$\begin{array}{c}\text { Total } \\
\text { Penerimaan } \\
(\mathbf{R p . 0 0 0 / t a h u n})\end{array}$} \\
\hline & & $\begin{array}{c}\text { Berprotei } \\
\text { n Tinggi } \\
\text { (Ton/th) }\end{array}$ & $\begin{array}{c}\text { Berprotein } \\
\text { Rendah } \\
\text { (Ton/th) }\end{array}$ & & & & \\
\hline 1 & 0,50 & 78.485 & 19.605 & 8.500 & 24.900 & 2.000 & 883.566 .262 \\
\hline 2 & 0,75 & 117.727 & 29.408 & 8.500 & 37.350 & 2.000 & 1.325 .349 .393 \\
\hline 3 & 1,00 & 156.970 & 39.211 & 8.500 & 49.800 & 2.000 & 1.767 .132 .524 \\
\hline 4 & 1,00 & 156.970 & 39.211 & 8.500 & 49.800 & 2.000 & 1.767 .132 .524 \\
\hline 5 & 1,00 & 156.970 & 39.211 & 8.500 & 49.800 & 2.000 & 1.767 .132 .524 \\
\hline 6 & 1,00 & 156.970 & 39.211 & 8.500 & 49.800 & 2.000 & 1.767 .132 .524 \\
\hline 7 & 1,00 & 156.970 & 39.211 & 8.500 & 49.800 & 2.000 & 1.767 .132 .524 \\
\hline 8 & 1,00 & 156.970 & 39.211 & 8.500 & 49.800 & 2.000 & 1.767 .132 .524 \\
\hline 9 & 1,00 & 156.970 & 39.211 & 8.500 & 49.800 & 2.000 & 1.767 .132 .524 \\
\hline 10 & 1,00 & 156.970 & 39.211 & 8.500 & 49.800 & 2.000 & 1.767 .132 .524 \\
\hline
\end{tabular}


Prakiraan penerimaan diperoleh dengan asumsi bahwa produk yang diproduksi terjual seluruhnya.

\section{Proyeksi Laba Rugi}

Laba rugi adalah selisih dari biaya yang diterima sebagai manfaat dan kegiatan bisnis dengan biaya yang dikeluarkan untuk menjalankan bisnis. Proyeksi laba rugi digunakan untuk mengetahui kegiatan yang dilakukan menguntungkan atau tidak bagi pihak internal maupun eksternal (Dwiatmini et al., 2001). Laba bersih adalah laba yang diperoleh sebelum pengurangan pajak. Pajak dihitung berdasarkan peraturan pemerintah tahun 2013 tentang pajak penghasilan yaitu sebesar $25 \%$ dari laba bersih untuk usaha yang memiliki penghasilan bersih diatas 50 milyar rupiah pertahun. Ringkasan proyeksi laba rugi dapat dilihat di Tabel 2.

\section{Proyeksi Arus Kas}

Perhitungan arus kas adalah dengan menghitung selisih antara aliran kas masuk dan aliran kas keluar setiap tahun. Arus kas terdiri atas arus kas bersih, arus kas awal tahun dan arus kas akhir tahun. Arus kas masuk industri tepung komposit terdiri atas laba bersih, biaya penyusutan, nilai sisa, dan pinjaman. Informasi mengenai arus kas menunjukkan kemampuan perusahaan dalam menghasilkan kas atau setara kas (Trisnawati, 2009). Arus kas keluar industri tepung komposit terdiri atas modal kerja, modal investasi tetap, angsuran modal kerja dan angsuran modal investasi tetap.Ringkasan arus kas industri tepung komposit dapat dilihat di Tabel 3.

\section{Pay-back period (PBP)}

PBP merupakan periode yang diperlukan bagi perusahaan untuk mengembalikan modal investasi total yang dihitung dari aliran kas bersih. Periode pengembalian perusahaan yang layak harus kurang dari waktu investasi, dalam kasus industri tepung komposit maka periode pengembalian harus kurang dari 10 tahun. Nilai NPV sama dengan 0 pada periode pengembalian. Periode pengembalian modal investasi pada industri tepung komposit adalah 3 tahun 6 bulan atau pada tahun ke-4 yang diperoleh dari perhitungan kriteria kelayakan investasi berdasar pada akumulasi pada tahun ke 3 sebesar Rp -134.751.891.795,- dan pada tahun ke 4 nilai akumulasi tidak lagi negatif sebesar Rp 127.995.873.561,-.

Tabel 2. Proyeksi laba rugi industri tepung komposit

\begin{tabular}{cccccc}
\hline $\begin{array}{c}\text { Tahun } \\
\text { ke- }\end{array}$ & $\begin{array}{c}\text { Total } \\
\text { Penerimaan }\end{array}$ & $\begin{array}{c}\text { Total } \\
\text { Pengeluaran }\end{array}$ & $\begin{array}{c}\text { Laba Sebelum } \\
\text { Pajak }\end{array}$ & $\begin{array}{c}\text { Pajak } \\
\text { Penghasilan }\end{array}$ & $\begin{array}{c}\text { Laba Setelah } \\
\text { Pajak }\end{array}$ \\
\cline { 2 - 6 } & $\mathbf{( R p . 0 0 0 / \text { tahun) }}$ & $\mathbf{( R p . 0 0 0 / \text { tahun) }}$ & $\mathbf{( R p . 0 0 0 / \text { tahun) }}$ & $\mathbf{( R p . 0 0 0 / \text { tahun) }}$ & $\mathbf{( \text { Rp.000/tahun) }}$ \\
\hline 1 & 883.566 .262 & 705.189 .985 & 178.376 .276 & 35.675 .255 & 142.701 .021 \\
2 & 1.325 .349 .393 & 1.032 .834 .591 & 292.514 .802 & 58.502 .960 & 234.011 .842 \\
3 & 1.767 .132 .524 & 1.360 .479 .196 & 406.653 .328 & 81.330 .666 & 325.322 .662 \\
4 & 1.767 .132 .524 & 1.360 .479 .196 & 406.653 .328 & 81.330 .666 & 325.322 .662 \\
5 & 1.767 .132 .524 & 1.360 .479 .196 & 406.653 .328 & 81.330 .666 & 325.322 .662 \\
6 & 1.767 .132 .524 & 1.360 .479 .196 & 406.653 .328 & 81.330 .666 & 325.322 .662 \\
7 & 1.767 .132 .524 & 1.360 .479 .196 & 406.653 .328 & 81.330 .666 & 325.322 .662 \\
8 & 1.767 .132 .524 & 1.360 .479 .196 & 406.653 .328 & 81.330 .666 & 325.322 .662 \\
9 & 1.767 .132 .524 & 1.360 .479 .196 & 406.653 .328 & 81.330 .666 & 325.322 .662 \\
10 & 1.767 .132 .524 & 1.360 .479 .196 & 406.653 .328 & 81.330 .666 & 325.322 .662 \\
\hline
\end{tabular}

Tabel 3. Ringkasan proyeksi arus kas industri tepung komposit

\begin{tabular}{cccccc}
\hline \multirow{2}{*}{$\begin{array}{c}\text { Tahun } \\
\text { ke- }\end{array}$} & $\begin{array}{c}\text { Arus Kas } \\
\text { Masuk }\end{array}$ & Arus Kas Keluar & Arus Kas Bersih & $\begin{array}{c}\text { Arus Kas Awal } \\
\text { Tahun }\end{array}$ & $\begin{array}{c}\text { Arus Kas Akhir } \\
\text { Tahun }\end{array}$ \\
\cline { 2 - 6 } (Rp. 000/tahun) & (Rp. 000/tahun) & (Rp. 000/tahun) & (Rp. 000/tahun) & (Rp. 000/tahun) \\
\hline 0 & 431.176 .755 & 431.176 .755 & & & \\
1 & 151.996 .518 & 144.618 .504 & 7.378 .014 & & 7.378 .014 \\
2 & 243.307 .339 & 187.873 .846 & 55.433 .493 & 7.378 .014 & 62.811 .507 \\
3 & 334.618 .159 & 173.082 .984 & 161.535 .175 & 62.811 .507 & 224.346 .682 \\
4 & 334.618 .159 & 99.526 .290 & 235.091 .869 & 224.346 .682 & 459.438 .551 \\
5 & 334.618 .159 & 92.962 .645 & 241.655 .514 & 459.438 .551 & 701.094 .064 \\
6 & 334.618 .159 & 86.399 .000 & 248.219 .159 & 701.094 .064 & 949.313 .223 \\
7 & 334.618 .159 & 79.835 .355 & 254.782 .804 & 949.313 .223 & 1.204 .096 .026 \\
8 & 334.618 .159 & 73.271 .710 & 261.346 .449 & 1.204 .096 .026 & 1.465 .442 .475 \\
9 & 334.618 .159 & 66.708 .065 & 267.910 .094 & 1.465 .442 .475 & 1.733 .352 .568 \\
10 & 452.680 .851 & 60.144 .420 & 392.536 .430 & 1.733 .352 .568 & 2.125 .888 .998 \\
\hline
\end{tabular}




\section{Break Even Point (BEP)}

Break Even Point (BEP) atau titik impas dapat dinyatakan dalam bentuk biaya produksi atau dalam bentuk kapasitas produksi. Titik impas merupakan titik dimana total penerimaan sama dengan total biaya produksi. Titik impas dalam bentuk biaya produksi industri tepung komposit sebesar Rp. 1.302.701.477.417,-. Titik impas kapasitas produksi tepung komposit adalah 153.258.997 Kg/tahun.

\section{Sistem Bagi Hasil}

Investasi merupakan kegiatan menyisihkan sebagian dana untuk ditempatkan pada sarana investasi untuk mendapatkan nilai ekonomis berupa keuntungan. Akan tetapi, menurut Syafrida et al. (2014), investor yang dalam kegiatan investasi ada yang tidak hanya mempertimbangkan aspek finansial berupa keuntungan namun mempertimbangkan nilainilai yang dianutnya, seperti ajaran agama. Investor yang demikian akan menolak berinvestasi pada perusahaan yang menghasilkan produk atau aktivitas bisnis yang bertentangan dengan prinsip agama (Guiso et al., 2004). Salah satu sarana dalam berinvestasi sesuai prinsip islam adalah dengan sistem bagi hasil (Siswantoro dan Qoyyimah, 2007). Sistem bagi hasil dihitung dengan menghitung perkalian antara total pendapatan dan bobot investor setiap tahun. Ringkasan sistem bagi hasil industri tepung komposit dapat dilihat di Tabel 4.

Pada perhitungan ini terdapat dua skenario yang dilakukan pada bagian bobot investor, yang pertama bobot investor \% berdasarkan biaya yang dikeluarkan investor dan yang kedua bobot investor $\%$ berdasarkan sistem kerja tiap investor sebelum dimasukkan ke perhitungan keuntungan, dari perhitungan proyeksi perkalian harga produk yaitu 8.500 dan 2.000 dan jumlah produk yaitu 78.485 dan 24.900 didapatkan nilai pendapatan sebesar 883.566.262 kemudian menghitung perkalian dengan bobot investor dengan hasil bobot investor I pada skenario pertama sebesar 618.496.383.

\section{Implikasi Manajerial}

Perencanaan bisnis yang telah dibuat mampu menjadi tolak ukur bagaimana mendirikan industri berbasis tepung komposit dengan bahan utama tepung terigu dan tepung lokal dengan sistem bagi hasil. Hasil analisis kelayakan bisnis cukup merepresentasikan kelayakan industri berdasar pada pemasaran dengan mengganti peran tepung terigu, penentuan harga yang sama dengan harga jual tepung terigu dan distribusi yang sama dengan pola distribusi tepung terigu. Sistem bagi hasil menunjukkan bahwa investor dapat berinvestasi dalam dua cara berdasarkan modal dan sistem kerja.

Salah satu keterbatasan terdapat pada ketersediaan tepung mocaf yang terbatas yaitu 29 ton/hari. Oleh karena itu diperlukan inisiasi industri tepung mocaf dan diperlukan kebijakan substitusi tepung terigu sebesar $10 \%$ agar kegiatan substitusi tepung terigu dapat diimplementasikan pada industri tepung terigu.

\section{KESIMPULAN DAN SARAN}

\section{Kesimpulan}

Faktor-faktor yang mempengaruhi perencanaan bisnis tepung komposit meliputi jumlah ketersediaan tepung lokal, jumlah konsumsi tepung terigu yang dapat digantikan dengan tepung komposit, perencanaan produksi, dan finansial dengan sistem bagi hasil. Faktor-faktor pendirian bisnis tepung komposit dipermudah dengan analisis dan pengambilan keputusan dengan perencanaan bisnis yang tepat dan akurat. Perencanaan bisnis tepung komposit dengan sistem bagi hasil dapat digunakan untuk membantu perancangan industri tepung komposit.

Tabel 4. Ringkasan sistem bagi hasil industri tepung komposit

\begin{tabular}{|c|c|c|c|c|c|c|}
\hline \multirow{3}{*}{$\begin{array}{c}\text { Tahun } \\
\text { ke- }\end{array}$} & \multicolumn{5}{|c|}{ Revenue Sharing (Bagi Hasil) (Rp 000/Tahun) } & \\
\hline & \multicolumn{2}{|c|}{$\begin{array}{c}\text { Skenario pertama (\% } \\
\text { berdasarkan biaya yang } \\
\text { dikeluarkan investor) }\end{array}$} & \multicolumn{4}{|c|}{ Skenario kedua (\% berdasarkan sistem kerja) } \\
\hline & $\begin{array}{c}\text { Investor I } \\
(70 \%)\end{array}$ & $\begin{array}{c}\text { Investor II } \\
(\mathbf{3 0 \%})\end{array}$ & $\begin{array}{c}\text { Investor I } \\
(\mathbf{5 0 \%})\end{array}$ & $\begin{array}{c}\text { Investor II } \\
(20 \%)\end{array}$ & $\begin{array}{c}\text { Investor III } \\
(20 \%)\end{array}$ & $\begin{array}{c}\text { Investor IV } \\
(10 \%)\end{array}$ \\
\hline 1 & 618.496 .383 & 265.069 .879 & 441.783 .131 & 176.713 .252 & 176.713 .252 & 88.356 .626 \\
\hline 2 & 927.744 .575 & 397.604 .818 & 662.674 .697 & 265.069 .879 & 265.069 .879 & 132.534 .939 \\
\hline 3 & 1236992767 & 530.139 .757 & 883.566 .262 & 353.426 .505 & 353.426 .505 & 176.713 .252 \\
\hline 4 & 1236992767 & 530.139 .757 & 883.566 .262 & 353.426 .505 & 353.426 .505 & 176.713 .252 \\
\hline 5 & 1236992767 & 530.139 .757 & 883.566 .262 & 353.426 .505 & 353.426 .505 & 176.713 .252 \\
\hline 6 & 1236992767 & 530.139 .757 & 883.566 .262 & 353.426 .505 & 353.426 .505 & 176.713 .252 \\
\hline 7 & 1236992767 & 530.139 .757 & 883.566 .262 & 353.426 .505 & 353.426 .505 & 176.713 .252 \\
\hline 8 & 1236992767 & 530.139 .757 & 883.566 .262 & 353.426 .505 & 353.426 .505 & 176.713 .252 \\
\hline 9 & 1236992767 & 530.139 .757 & 883.566 .262 & 353.426 .505 & 353.426 .505 & 176.713 .252 \\
\hline 10 & 1236992767 & 530.139 .757 & 883.566 .262 & 353.426 .505 & 353.426 .505 & 176.713 .252 \\
\hline
\end{tabular}


Hasil analisis menunjukkan bahwa tepung tapioka dan tepung mocaf berpotensi sebagai pengganti tepung terigu. Berdasarkan ketersediaan bahan baku, tepung mocaf memiliki ketersediaan paling sedikit yakni 10.000 ton/tahun, maka tepung mocaf yang dapat disediakan untuk substitusi sebagian tepung terigu adalah 29 ton/hari. Tepung mocaf yang di substitusi sebesar 5\% dan tepung tapioka sebesar 5\%. Hasil analisis kelayakan bisnis tepung komposit menunjukkan payback periode selama 3 tahun 6 bulan dan Break Even Point (BEP) adalah 153.258.997 Kg/tahun. Hasil tersebut telah membuktikan bahwa bisnis ini telah layak untuk dijalankan. Sistem bagi hasil yang ditetapkan adalah sistem bagi hasil pendapatan (revenue sharing) sesuai dengan rekomendasi Dewan Syariah Nasional. Penelitian ini telah berhasil memodelkan dua skenario bagi hasil untuk investor yang terlibat dalam bisnis

\section{Saran}

Manajemen dan analisis risiko dalam perancangan pabrik sebaiknya dilakukan. Penggunaan metode sistem syariah yang lain sebagai pembanding sebaiknya dilakukan.

\section{DAFTAR PUSTAKA}

Abdullah MM. 2014. Manajemen Bisnis Syariah. Yogyakarta (ID): Aswaja Pressindo.

[Aptindo] Asosiasi Produsen Tepung Terigu Indonesia. 2017. Indonesia: wheat flour industry overview. http://aptindo.or.id/overview/ [9 $\quad$ Maret 2017].

Badan Pusat Statistik. 1987. Analisa Perbandingan Industri Besar/Menengah, Kecil dan Rumah Tangga. Jakarta.

Djazuli A. 2006. Kaidah-Kaidah Fikih: Kaidah Hukum Islam Dalam Menyelesaikan Masalah-Masalah Yang Praktis. Jakarta (ID): Kencana.

DSN (Dewan Syariah Nasional).2000. Pembiayaan Mudharabah (Qiradh). Jakarta (ID): DSNMUI.

Dwiatmini S, Sesilia, Nurkholis. 2001. Analisis reaksi pasar terhadap informasi laba: kasus praktek perataan laba pada perusahaan yang terdaftar di bursa efek Jakarta. TEMA. Malang. 2(1): 35-48.

Eschenbach TG. 1992. Quick sensitivity analysis for small project and feasibility studies. Proquest Science Journal. 2(6): 1-8.

Firdaus MR, Widyarfendhi, Rusniati, Respati NW. 2017. Analysis on the substitution abillity of mocaf toward wheat flour, its business feasibility, and its industry multiple effects. Journal Wetlands Environmental Management. 5(2): 23-33.
Guiso LSP dan Zingales L. 2004. The role of social capital in financial development. The American Economic Review. 94(3).

Hadi A. 2013. Rencana bisnis pembuatan mi basah menggunakan tepung modified cassava flour (mocaf). [tesis]. Yogyakarta (ID): Universitas Gadjah Mada.

Iqbal M dan Molyneux P. 2005. Thirty Years of Islamic Banking: History, Perfomance and Prospects. Palgrave Macmillan: Hampshire. UK.

Kardono dan Hanani N. 2004. Teori Ekonomi Mikro. Malang (ID): University Brawijaya.

Kasmir J. 2004. Studi Kelayakan Bisnis. Jakarta (ID): Kencana.

Lala FH, Susilo B, dan Komar R. 2013. Uji Karakteristik Mie Instan Berbahan-Baku Tepung Terigu dengan Substitusi Mocaf.J Bio Kom Trop. 1(2).

Marimin dan Sutiyono A. 2002. Model Sistem Manajemen Ahli Perencanaan Investasi Produk Agroindustri Komoditas Umbiumbian. Didalam : Prosiding Komputer dan Sistem Intelijen. [21-22 Agustus 2002]. Jakarta (ID): Universitas Gunadarma. 2837.

Pardiansyah E. 2017. Investasi dalam perspektif ekonomi islam: pendekatan teoritis dan empiris. Economica: Jurnal Ekonomi Islam. Jakarta. 8(2).

Rangkuti F. 2005. Analisis SWOT : Teknik Membedah Kasus Bisnis. Jakarta (ID): PT Gramedia.

Richana N. 2010. Tepung jagung termodifikasi sebagai pengganti terigu. War Penelit dan Pengemb Pertan. 32(6): 15-21.

Segrado C. 2005. Islamic Microfinance and Socially Responsible Invesments. Torino: University of Torino.

Siswantoro D dan Qoyyimah H. 2007. Analysis on the feasibility study of musharakah mutanaqisah implementation in Indonesian islamic banks. Advances in Islamic Economics and Finance. Jeddah. 1:471488.

Subagio A. 2007. Industrialisasi Modified Cassava Flour (MOCAF) sebagai Bahan Baku Industri Pangan untuk Menunjang Diversifikasi Pangan Pokok Nasional. Jember (ID): Fakultas Teknologi Pertanian.

Subagyo A. 2008. Studi Kelayakan Teori dan Aplikasi. Jakarta (ID): Gramedia.

Syafrida I, Aminah I, Waluyo B. 2014. Perbandingan kinerja instrumen investasi berbasis syariah dengan konvensional pada pasar modal di Indonesia. Al-Iqtishad. Jakarta. 6(2):196-206.

Syah D, Hariyadi RD, Firlieyanti AS, Koswara S. 2009. Potensi Pengembangan Ubijalar 
dalam Mendukung Diversifikasi Pangan. Bogor (ID): SEAFAST Centre Pr.

Trisnawati I. 2009. Pengaruh economic value added, arus kas operasi, residiul income, earnings, operating leverage dan market value terhadap return saham. Jurnal Bisnis dan Akuntansi. 11(1): 65-78.

Umar H. 2003. Study of Business Feasibility. Edition 2. Jakarta (ID): Gramedia.

US Wheat Assosiates. 1981. Pedoman Pembuatan Roti dan Kue (terjemahan). Jakarta(ID): Djambatan.
Widowati S. 2009. Tepung Aneka Umbi Sebuah Solusi Ketahanan Pangan. URL http://www.litbang.pertanian.go.id/artikel.p hp/one/240/pdf/Tepung\%20Aneka\%20Um bi\%20Sebuah\%20Solusi \%20Ketahanan $\% 2$ OPangan.pdf (diakses 11 Februari 2019).

Yulifianti R, Ginting E, dan Utomo JK. 2012. Tepung kasava modifikasi sebagai bahan substitusi terigu mendukung diversifikasi pangan. Buletin Palawijaya. 23: 1-12 